\title{
Differences in the clinical-epidemiological profile between new cases of tuberculosis and retreatment cases after default*
}

\author{
Diferenças no perfil clínico-epidemiológico entre casos novos de \\ tuberculose e casos em retratamento após abandono \\ Diferencias en el perfil clínico-epidemiológico entre casos nuevos \\ de tuberculosis y casos en retratamiento tras abandono
}

\section{Aylana de Souza Belchior ${ }^{1}$, Ricardo Alexandre Arcêncioº ${ }^{2}$ Evelyne Marie Therese Mainbourg ${ }^{3}$}

\section{How to cite this article:}

Belchior AS, Arcêncio RA, Mainbourg EMT. Differences in the clinical-epidemiological profile between new cases of tuberculosis and retreatment cases after default. Rev Esc Enferm USP. 2016;50(4):619-625. DOI: http://dx.doi.org/10.1590/S0080-623420160000500012

* Extracted from the thesis "O conhecimento dos pacientes acerca da tuberculose”, Programa de Pós-Graduação em Enfermagem,

Universidade Federal do Amazonas, Universidade do Estado do Pará, 2012.

${ }^{1}$ Universidade Federal do Amazonas, Escola de Enfermagem de Manaus, Programa de PósGraduação em Enfermagem, Manaus, AM, Brazil.

${ }^{2}$ Universidade de São Paulo, Escola de Enfermagem de Ribeirão Preto, Ribeirão Preto, SP, Brazil.

${ }^{3}$ Fundação Oswaldo Cruz, Instituto Leônidas e Maria Deane, Manaus, AM, Brazil.

\begin{abstract}
Objective: To identify the socioeconomic and clinical-epidemiological factors related to tuberculosis in new cases and retreatment cases. Method: Comparative study with 126 patients, of which 42 were retreatment cases after default attended in a reference center, and 84 were new cases completing the first treatment and treated in Basic Health Units. The collection of primary data was through interview, and of secondary data by records of the Notifiable Diseases Information System. Comparative analysis between the two groups. Results: The new cases differ from retreatment cases regarding educational level. The clinical-epidemiological profile shows a significant difference in relation to performance of the tuberculin skin test, and the HIV test result (positive) in favor of new cases. In relation to performance of sputum culture and the result (positive) of the first sputum smear of the first and second samples, in favor of retreatment cases. Conclusion: The two groups are significantly different in clinical and epidemiological characteristics that show the access to exams.
\end{abstract}

\section{DESCRIPTORS}

Tuberculosis; Patients; Patient Dropouts; Epidemiology; Health Profile; Public Health Nursing.
Corresponding author:

Evelyne Marie Therese Mainbourg

Instituto Leônidas e Maria Deane

Rua Teresina, 476 - Adrianópolis

CEP 69057-070 - Manaus, AM, Brasil

evelyne.mainbourg@gmail.com
Received: 09/17/2015

Approved: 05/30/2016 


\section{INTRODUCTION}

Tuberculosis (TB) is a major public health problem. A third of the population is infected with Mycobacterium tuberculosis. Twenty-two countries account for $80 \%$ of the TB burden, and Brazil is in $16^{\text {th }}$ place in terms of incidence ${ }^{(1)}$.

According to the World Health Organization (WHO), 'new cases' are all patients with tuberculosis who have never used antituberculosis drugs, or used them for less than a month, and were diagnosed through laboratory or radiological tests, or clinical criteria. Retreatment is when the person did the TB treatment for more than 30 days and needs a new treatment for recurrence after cure (RC) or return after abandonment $(\mathrm{RA})^{(2)}$.

In Brazil, between 2005 and 2014, were diagnosed 73,000 new cases of tuberculosis per year on average, accounting for an incidence rate of 33.5/100,000 inhabitants. In $2013,72.5 \%$ of cases of pulmonary TB were cured, a result still inferior to the goal recommended by the $\mathrm{WHO}^{(3)}$. Of these cases, $10.9 \%$ abandoned the treatment, and 4,577 people died ${ }^{(1)}$.

The state of Amazonas has the highest TB incidence rate in the country $(68.4 / 100,000$ inhabitants), twice the national average. Manaus, the state capital, has contributed significantly to this scenario, because in 2013 was recorded the incidence rate of 93.8 cases per 100 thousand inhabitants in the city, while the national average was 33.5 cases per 100 thousand inhabitants ${ }^{(1)}$. Regarding abandonment, in the same year was recorded the treatment abandonment percentage of $18 \%$ in Manaus ${ }^{(1)}$, almost double the national average (10.9\%).

Some published studies have already addressed the factors associated with treatment abandonment ${ }^{(4-9)}$ However, in addition to factors associated with abandonment, was considered the profile of patients who return to treatment. What characterizes these subjects? What are the differences between these patients in relation to new cases, which are also likely to abandon treatment, but mostly reach the cure in their first treatment? Some studies have found the low educational level and previous abandonment as factors associated with abandonment ${ }^{(10)}$. Other studies found the association between young age, alcohol abuse, unemployment, low educational level and abandonment of prior treatment with abandonment ${ }^{(11)}$. However, there were no studies characterizing these patients with the view to support health services actions aimed specifically at such patients. The profile can indicate subsidies to conduct treatment, and thus avoid new episodes of abandonment. On the other hand, in a study on the profile of notified tuberculosis cases and factors associated with abandonment performed in the state of Minas Gerais, the results showed the independent association between treatment abandonment and the use of drugs, interest in treatment and information about the disease ${ }^{(12)}$.

The aim of this study was to identify differences in socioeconomic and clinical-epidemiological profile between new cases of TB and retreatment cases after default.

\section{METHOD}

This is a comparative cross-sectional study. Sixty-two cases in retreatment were identified after treatment abandonment in 2011, which in that situation were followed in the Reference Center in Sanitary Pneumology of the state of Amazonas, Brazil. The new cases were collected from data of the Basic Health Units where the retreatment cases had previously performed the treatment that was abandoned. The objective of this procedure was to identify patients with similar characteristics, living conditions, treatment conditions, and access to health services.

Since it was not possible to locate 20 patients (32\%) of the 62 in retreatment, were recruited 42 patients in retreatment after default in 2011, and 84 new cases of TB completing the first treatment between December 2011 and April 2012. The new cases were selected in the ratio of 2 to 1 until reaching the proposed number of subjects.

Inclusion criteria were age over 18 years and having had the first treatment in the city of Manaus. Given that Manaus accounts for about 70\% of the TB notifications of the state of Amazonas, the study was focused only in the capital city.

Data were collected through the application of an interview form prepared for this study and previously tested. The interviews were conducted by a single researcher (member of the research team), lasted 20 to 30 minutes, and were held in the health service or the residence of the subject, according to each individual's preference. The form included questions about the socioeconomic profile of subjects: sex, age range, race/color, marital status, educational level, occupation, income and lifestyle. Clinical, laboratory and epidemiological data were obtained from the medical records of the subject or from the notification/investigation records of the Notifiable Diseases Information System (Sinan Sistema de Informação de Agravos de Notificação).

The Student's t test and then, the Levene's test were used to certify the homoscedasticity of variances in the analysis of the educational level variable. For the comparison of proportions between the variables of interest (according to the subject's condition: new case or retreatment case after default), was used the Pearson's chi-square test $\left(\mathrm{X}^{2}\right)$ with Yates correction or Fisher's exact test, when appropriate. The type I error was set at 5\% for all tests.

The project was approved by the Research Ethics Committee of the Universidade Federal do Amazonas (CEP/UFAM) under number CAAE 0441.0.115.000-11, and the study subjects signed the Informed Consent form (IC).

\section{RESULTS}

Table 1 shows the differences of socioeconomic profile between new cases and cases in retreatment for tuberculosis. Note that the only variable with statistically significant difference between the two groups is educational level (average of years of study), which is higher for new cases. In the other variables, groups are similar. 
Table 1 - Socioeconomic characteristics of new cases and retreatment cases of tuberculosis - Manaus, AM, Brazil, 2011.

\begin{tabular}{|c|c|c|c|}
\hline Variables & $\begin{array}{c}\text { Retreatment cases } \\
\text { n (\%) }\end{array}$ & $\begin{array}{c}\text { New cases } \\
n(\%)\end{array}$ & P-value \\
\hline \multicolumn{4}{|l|}{ Gender } \\
\hline Male & $28(66.7)$ & $49(58.3)$ & 0.3600 \\
\hline Female & $14(33.3)$ & $35(41.7)$ & \\
\hline \multicolumn{4}{|l|}{ Age range (years) } \\
\hline 18 to 29 & $11(26.2)$ & $24(28.2)$ & 0.9800 \\
\hline 30 to 39 & $11(26.2)$ & $21(25.0)$ & \\
\hline 40 to 49 & $9(21.4)$ & $19(22.6)$ & \\
\hline 50 or over & $11(26.2)$ & $20(23.8)$ & \\
\hline \multicolumn{4}{|l|}{ Color/Race } \\
\hline Asian & $3(7.1)$ & $9(10.7)$ & 0.1200 \\
\hline White & $2(4.8)$ & $11(13.1)$ & \\
\hline Indigenous & $2(4.8)$ & $0(0.0)$ & \\
\hline Mixed race & $29(69.0)$ & $57(67.9)$ & \\
\hline Black & $6(14.3)$ & $7(8.3)$ & \\
\hline \multicolumn{4}{|l|}{ Marital status } \\
\hline Single, widowed, separated, divorced & $13(31.0)$ & $37(44.0)$ & 0.1500 \\
\hline Married, common-law marriage & $29(69.0)$ & $47(56.0)$ & \\
\hline \multicolumn{4}{|l|}{ Educational level (years of study) } \\
\hline Average (SD) & $5.9(3.7)$ & $7.9(4.3)$ & $0.0110 \S$ \\
\hline \multicolumn{4}{|l|}{ Occupation } \\
\hline With occupation & $25(59.5)$ & $56(66.7)$ & 0.3300 \\
\hline No occupation & $17(40.5)$ & $28(33.3)$ & \\
\hline \multicolumn{4}{|l|}{ Type of occupation } \\
\hline Autonomous & $8(19.0)$ & $15(17.9)$ & 0.7700 \\
\hline Unemployed, house worker, student & $13(31.0)$ & $24(28.6)$ & \\
\hline Top member of public service & $4(9.5)$ & $15(17.9)$ & \\
\hline Service worker & $8(19.0)$ & $12(14.3)$ & \\
\hline Repair worker & $9(21.4)$ & $18(21.4)$ & \\
\hline \multicolumn{4}{|l|}{ Income } \\
\hline No income & $9(21.4)$ & $15(17.9)$ & 0.6300 \\
\hline Less than a minimum wage** & $4(9.5)$ & $14(16.7)$ & \\
\hline One to two minimum wages** & $24(57.1)$ & $42(50.0)$ & \\
\hline More than two minimum wages** & $5(11.9)$ & $13(15.5)$ & \\
\hline Total & $42(100)$ & 84(100) & \\
\hline
\end{tabular}

$\mathrm{SD}=$ standard deviation.

$\S=$ Student's t test.

** = Minimum wage value: $\mathrm{R} \$ 622.00$ in December 2011 (Banco Central do Brasil).

Note: $\mathrm{p}$ in bold corresponds to statistical significance level of $5 \%$.

Table 2 shows the clinical and epidemiological characterization of new cases of TB and retreatment cases after default. Significant differences can be identified in the use of tuberculin skin test (favoring new cases), sputum culture (retreatment cases), the results of sputum smear microscopy in the first and second samples (positive in retreatment cases) and the HIV test results (positive in new cases). 
Table 2 - Clinical and epidemiological characteristics of new cases and retreatment cases of tuberculosis patients - Manaus, AM, Brazil, 2011.

\begin{tabular}{|c|c|c|c|}
\hline Variables & Retreatment cases $\mathbf{n}(\%)$ & New cases n (\%) & P-value \\
\hline \multicolumn{4}{|l|}{ Chest X-ray } \\
\hline Not performed & $4(9.5)$ & $15(17.9)$ & 0.2200 \\
\hline Performed & $38(90.5)$ & $69(82.1)$ & \\
\hline \multicolumn{4}{|l|}{ Result } \\
\hline Abnormal & $36(94.7)$ & $64(92.8)$ & 0.6900 \\
\hline Normal & $2(5.3)$ & $5(7.2)$ & \\
\hline \multicolumn{4}{|l|}{ Tuberculin skin test } \\
\hline Not performed & 41(97.6) & $53(63.1)$ & $0.0000^{* *}$ \\
\hline Performed & $1(2.4)$ & $31(36.9)$ & \\
\hline \multicolumn{4}{|l|}{ Result } \\
\hline Positive & $0(0.0)$ & 26(83.9) & $0.1800^{\mathrm{a}}$ \\
\hline Negative & $1(100)$ & $5(16.1)$ & \\
\hline \multicolumn{4}{|l|}{ Clinical form } \\
\hline Pulmonary & 39(92.9) & $64(76.2)$ & 0.0700 \\
\hline Extrapulmonary & $3(7.1)$ & 19(22.6) & \\
\hline Pulmonary + extrapulmonary & $0(0.0)$ & $1(1.2)$ & \\
\hline \multicolumn{4}{|l|}{ Extrapulmonary } \\
\hline Cutaneous & $0(0.0)$ & $2(10.0)$ & 1.0000 \\
\hline Peripheral ganglionic & $1(33.3)$ & $5(25.0)$ & \\
\hline Bone & $0(0.0)$ & $1(5.0)$ & \\
\hline Anal & $0(0.0)$ & $3(15.0)$ & \\
\hline Pleural & $2(66.7)$ & $9(45.0)$ & \\
\hline \multicolumn{4}{|l|}{ Bacilloscopy $1^{\text {st }}$ sample } \\
\hline Not performed & $3(7.1)$ & $12(14.3)$ & 0.2400 \\
\hline Performed & 39(92.9) & $72(85.7)$ & \\
\hline \multicolumn{4}{|l|}{ Result } \\
\hline Positive & $33(84.6)$ & $47(65.3)$ & 0.0300* \\
\hline Negative & 6(15.4) & $25(34.7)$ & \\
\hline \multicolumn{4}{|l|}{ Bacilloscopy $2^{\text {nd }}$ sample } \\
\hline Not performed & $3(7.1)$ & $14(16.7)$ & 0.1400 \\
\hline Performed & 39(92.9) & $70(83.3)$ & \\
\hline \multicolumn{4}{|l|}{ Result } \\
\hline Positive & $30(76.9)$ & $32(45.7)$ & $0.0000^{*}$ \\
\hline Negative & $9(23.1)$ & $38(54.3)$ & \\
\hline \multicolumn{4}{|l|}{ Sputum culture } \\
\hline Not performed & $17(40.5)$ & 75(89.29) & 0.0000* \\
\hline Performed/in progress & $25(59.5)$ & $9(10.71)$ & \\
\hline \multicolumn{4}{|l|}{ Result } \\
\hline Positive & $18(72)$ & $5(55.6)$ & 0.4200 \\
\hline Negative & $7(28)$ & $4(44.4)$ & \\
\hline \multicolumn{4}{|l|}{ HIV test } \\
\hline Not performed & $21(50.0)$ & $43(43.4)$ & 0.5700 \\
\hline Performed/in progress & $21(50.0)$ & $56(56.6)$ & \\
\hline \multicolumn{4}{|l|}{ Result } \\
\hline Positive & $1(4.8)$ & $9(34.6)$ & 0.0100* \\
\hline Negative & $20(95.2)$ & $17(65.4)$ & \\
\hline
\end{tabular}

continued... 


\begin{tabular}{|c|c|c|c|}
\hline Variables & Retreatment cases $\mathbf{n}(\%)$ & New cases $n(\%)$ & P-value \\
\hline \multicolumn{4}{|c|}{ Associated diseases } \\
\hline \multicolumn{4}{|l|}{ Aids } \\
\hline Yes & $2(4.8)$ & $10(11.9)$ & $0.6400^{*}$ \\
\hline No or unknown & $40(95.2)$ & $74(88.1)$ & \\
\hline \multicolumn{4}{|l|}{ Alcoholism } \\
\hline Yes & $7(16.7)$ & $8(9.5)$ & 0.2432 \\
\hline No or unknown & $35(83.3)$ & $76(90.5)$ & \\
\hline \multicolumn{4}{|l|}{ Mental disease } \\
\hline Yes & $0(0.0)$ & $1(1.2)$ & $0.4777^{*}$ \\
\hline No or unknown & $42(100.0)$ & 83(98.8) & \\
\hline \multicolumn{4}{|l|}{ Diabetes } \\
\hline Yes & $1(2.4)$ & $8(9.5)$ & $0.1422^{*}$ \\
\hline No or unknown & $41(97.6)$ & $76(90.5)$ & \\
\hline Total & $42(100)$ & 84(100) & \\
\hline
\end{tabular}

*Fisher's exact test (5\% significance level).

Note: $\mathrm{p}$-value in bold corresponds to statistical significance level of 5\%.

The patients of new cases have higher educational level, are more easily subjected to the tuberculin test, and have positive HIV test results in a higher proportion. The patients of retreatment cases are more easily subjected to sputum culture, and have positive results of the sputum smear microscopy, both in the first and the second sample, in a higher proportion.

\section{DISCUSSION}

The group of patients who completed the TB treatment (new cases) and the group in retreatment after default were studied at the same time. The new cases were selected from the same population source that cases in retreatment, which avoids possible biases. Moreover, this is the most common form of studying events related to the end outcome of $\mathrm{pa}^{-}$ tients with tuberculosis. In most studies, it is common to find incorrect or dubious information, especially with reference to habits and risk factors (smoking, consumption of alcohol or drugs). In our study, this was not different.

As in many studies of different areas, note that the educational level variable shows significant differences between the analyzed groups. In this study, the number of years of education among new cases of tuberculosis is $25 \%$ higher on average, compared to cases in retreatment. This data is similar to the results presented in the 2012 Epidemiological Bulletin $^{(13)}$, and shows the considerable importance of school education in the conduct adopted before a health problem with symptoms sometimes insidious and subject to prejudice.

By analyzing the complementary tests, it was found that in almost all patients who abandoned treatment, the tuberculin skin test had not been done, while over half of new cases did not do this test. Corroborating this finding, previous studies have shown that in most reported cases of tuberculosis, both the new and retreatment, the tuberculin skin test was not done ${ }^{(14-15)}$. However, according to the Manual of recommendations for the control of tuberculosis ${ }^{(2)}$, the tuberculin skin test is indicated for populations at high risk of infection and illness from tuberculosis: people living with HIV-AIDS and professionals working in health services where there are $\mathrm{TB}$ patients. The justification for not performing the tuberculin test is based on this information, since in the study it was identified that the vast majority of patients did not have health problems related to tuberculosis, such as AIDS, alcoholism, mental illness and diabetes. Other studies support this finding ${ }^{(12,16)}$.

Regarding the completion of laboratory tests, in retreatment cases, both in the first and the second sample, the smear result was positive for at least three out of four patients. Among new cases, the result of the first sample was positive for two thirds of patients, while in the second sample, less than half of results was positive. The predominance of positive results in sputum smear microscopy has already been described ${ }^{(17-18)}$. However, this finding cannot be attributed to the fact that health services prioritize patients in retreatment for performing sputum smear microscopy, since this examination is a priority for patients seeking health services for respiratory problems or radiological changes in the lungs.

Culture is a method of high specificity and sensitivity in TB diagnosis. In pulmonary cases with negative bacilloscopy, the sputum culture can increase the bacteriological diagnosis of the disease in up to $30 \%^{(2)}$. In this study, the number of cases in retreatment who did the sputum culture is almost the triple of new cases. In fact, cases in retreatment are more easily subject to completion of sputum culture in routine service, considering that these patients were diagnosed as having contracted tuberculosis, but require a more accurate laboratory diagnosis. In contrast, new cases should do the tuberculin skin test first.

The Ministry of Health recommends performing the HIV serology test in all cases diagnosed with tuberculosis ${ }^{(2)}$. In practice, though, this does not occur. The findings showed that only half of patients in retreatment and a little over half of new cases underwent serologic testing for HIV. Although this 
is not a satisfactory result, there are more serious situations, such as in Salvador ${ }^{(19)}$, where only $6.6 \%$ of patients diagnosed with TB underwent HIV serology testing.

In a study, the difference of serological HIV testing results between two groups was significant; more than a third of new cases were positive compared with less than $5 \%$ of positive for cases in retreatment. In a study performed in Recife, where the incidence of TB-HIV $\mathrm{co}^{-}$ infection was $12.7 / 100,000$ inhabitants in 2012, similar to Manaus in the same year $(14.7 / 100,000 \text { inhabitants })^{(3)}$, only $2.4 \%$ of cured cases were positive compared to less than $4 \%$ of positive results among cases in retreatment ${ }^{(10)}$. Hence, the result of this study should not be generalized, because the sample size is very small and these are secondary data.

As for educational level, the greater number of years of study of new cases may explain the increased accessibility to the health system and less abandonment of treatment.

Some methodological limitations may have affected this study results. The first refers to the fact that some of the associations found did not reach significance, which could be attributed to lack of statistical power. Another limitation could be related to a possible recall bias.

\section{CONCLUSION}

The data presented indicate that knowing the profile of TB patients allows to alert the program about possible risks of treatment abandonment in order to prevent the spread of disease and increased morbidity and mortality.

The results suggest conducting further studies, since the socioeconomic characteristics were not associated with retreatment. There was little surprise in relation to clinical and epidemiological characteristics. Therefore, the explanation of having to repeat the treatment should be sought in other variables.

It is expected that this study results arouse reflections in health professionals, provide support for the intensification of educational activities by the teams, and contribute significantly to improve the health actions related to $\mathrm{pa}^{-}$ tients undergoing tuberculosis treatment.

This study should expand discussions on the topic, contributing to teaching/research, and mainly to improvement of care, emphasizing the need for patients following treatment until the cure of a disease that has evolved rapidly in recent years, in order to reduce the number of cases of treatment abandonment.

\section{RESUMO}

Objetivo: Identificar fatores socioeconômicos e clínico-epidemiológicos associados à tuberculose em casos novos e em casos em retratamento. Método: Estudo comparativo de 126 pacientes, sendo 42 casos em retratamento por abandono atendidos num Centro de Referência e 84 casos novos concluindo o primeiro tratamento, atendidos em Unidades Básicas de Saúde. Levantamento de dados primários por entrevista e dados secundários pela Ficha de Informação de Agravos de Notificação. Análise comparativa entre os dois grupos. Resultados: Os casos novos diferem dos em retratamento quanto à escolaridade. O perfil clínico-epidemiológico mostra que há diferença significativa quanto à realização do teste tuberculínico e o resultado do teste HIV (positivo) a favor dos casos novos. Quanto à realização da cultura de escarro e o resultado (positivo) da baciloscopia de escarro da primeira e da segunda amostras, a favor dos casos em retratamento. Conclusão: Os dois grupos diferem significativamente por características clínico-epidemiológicas que retratam o acesso a exames.

\section{DESCRITORES}

Tuberculose; Pacientes; Pacientes Desistentes do Tratamento; Epidemiologia; Perfil de Saúde; Enfermagem em Saúde Pública.

\section{RESUMEN}

Objetivo: Identificar factores socioeconómicos y clínico-epidemiológicos asociados con la tuberculosis en casos nuevos y en casos en retratamiento. Método: Estudios comparativo de 126 pacientes, siendo 42 casos en retratamiento por abandono atendidos en un Centro de Referencia y 84 casos nuevos concluyendo el primer tratamiento, atendidos en Unidades Básicas de Salud. Relevamiento de datos primarios por entrevista y datos secundarios por la Ficha de Información de Agravios de Notificación. Análisis comparativo entre ambos grupos. Resultados: Los casos nuevos difieren de los en retratamiento en cuanto a la escolaridad. El perfil clínico-epidemiológico muestra que hay diferencia significativa en cuanto a la realización de la prueba tuberculínica y el resultado de la prueba VIH (positivo) a favor de los casos nuevos. En cuanto a la realización del cultivo de esputo y el resultado (positivo) de la baciloscopia de esputo de la primera y la segunda muestras, están a favor de los casos en retratamiento. Conclusión: Ambos grupos difieren significativamente por características clínico-epidemiológicas que retratan el acceso a estudios.

\section{DESCRIPTORES}

Tuberculosis; Pacientes; Pacientes Desistentes del Tratamiento; Epidemiología; Perfil de Salud; Enfermería en Salud Pública.

\section{REFERENCES}

1. Boletim Epidemiológico. Tuberculose. Brasília: Ministério da Saúde, Secretaria de Vigilância em Saúde [Internet]. 2015 [citado 2015 jul. 22];46(9):1-19. Disponível em: http://portalsaude.saude.gov.br/images/pdf/2015/marco/27/2015-007---BE-Tuberculose---para-substitui---o-no-site.pdf

2. Brasil. Ministério da Saúde; Secretaria de Vigilância em Saúde. Programa Nacional de Controle da Tuberculose. Manual de recomendações para o controle da tuberculose no Brasil. Brasília: MS; 2011. 
3. Brasil. Ministério da Saúde; Secretaria de Vigilância em Saúde, Departamento de Vigilância das Doenças Transmissíveis. Programa da Tuberculose no Brasil. Indicadores epidemiológicos e operacionais. Brasília: MS; 2014.

4. Ajao KO, Ogundun AO, Afolabi OT, Ojo TO, Atiba BP, Oguntunase DO. Treatment compliance and challenges among tuberculosis patients across selected health facilities in Osun State Nigeria. Afr J Med Med Sci. 2014;43 Suppl:21-9.

5. Fluegge KR. Using spatial disease patterns and patient-level characteristics to describe prevalence elastic behavior in treatment for Latent Tuberculosis Infection (LTBI). Public Health Nurs. 2015;32(5):517-31.

6. Putera I, Pakasi TA, Karyadi E. Knowledge and perception of tuberculosis and the risk to become treatment default among newly diagnosed pulmonary tuberculosis patients treated in primary health care, East Nusa Tenggara: a retrospective study. BMC Res Notes. $2015 ; 8: 238$.

7. Craig GM, Zumla A. The social context of tuberculosis treatment in urban risk groups in the United Kingdom: a qualitative interview study. Int J Infect Dis. 2015;32:105-10.

8. Wei XL, Yin J, Zou GY, Zhang ZT, Walley J, Harwell J, et al. Treatment interruption and directly observed treatment of multidrug-resistant tuberculosis patients in China. Int J Tuberc Lung Dis. 2015;19(4):413-9.

9. Silva PF, Moura GS, Caldas AJM. Fatores associados ao abandono do tratamento da tuberculose pulmonar no Maranhão, Brasil, no período de 2001 a 2010. Cad Saúde Pública. 2014;30(8):1745-54.

10. Silva CCAV, Andrade MS, Cardoso MD. Fatores associados ao abandono do tratamento de tuberculose em indivíduos acompanhados em unidades de saúde de referência na cidade do Recife, Estado de Pernambuco, Brasil. Epidemiol Serv Saúde. 2013;22(1):77-85.

11. Furlan MCR, Oliveira SP, Marcon SS. Factores associated with nonadherence of tuberculosis treatment in the state of Paraná. Acta Paul Enferm. 2012;25(n.spe):108-14.

12. Paixão LMM, Gontijo ED. Profile of notified tuberculosis cases and factors associated with treatmente dropout. Rev Saúde Pública. 2007;41(2):205-13.

13. Boletim Epidemiológico. Tuberculose. Brasília: Ministério da Saúde, Secretaria de Vigilância em Saúde [Internet]. 2012 [citado 2015 jul. 22];43(1):15-9. Disponível em: http://portalsaude.saude.gov.br/images/pdf/2014/julho/23/BE-2012-43--1--pag-15-19-Tuberculoseno-Brasil.pdf

14. Oliveira SMVL, Ruffino-Netto A, Paniago AMM, Oliveira AO, Marques M, Cunha RV, et al. Tuberculin skin test: operational research in the state of Mato Grosso do Sul, Brazil. J Bras Pneumol. 2011;37(5):646-54.

15. Maciel, ELN, Martinato, CA, Bandeira, CFR, Tonini MS, Dietze R, Ramos MC. Epidemiologic study of tuberculosis in child and adolescents less than 15 years old in Grand Vitória-ES, Brazil, from 1990 to 2001. Cad Saúde Colet. 2006; 14(1): 81-94.

16. Braga JU, Pinheiro JS, Matsuda JS, Barreto JAPB, Feijão AMM. Factors associated with noncompliance with tuberculosis treatment in primary care services in two Brazilian cities, Manaus and Fortaleza, from 2006 to 2008. Cad Saúde Colet. 2012; 20(2):225-33.

17. Belo EM, Orellana JDY, Levino A, Basta PC. Tuberculose nos municípios amazonenses da fronteira Brasil-Colômbia-Peru-Venezuela: situação epidemiológica e fatores associados ao abandono. Rev Panam Salud Publica. 2013;34(5):321-9.

18. Durans JJF, Sá EM, Pereira LFB, Soares DL, Oliveira PS, Aquino DMC, et al. Perfil clínico e sociodemográfico de pacientes que abandonaram o tratamento de tuberculose no Município de São Luís - MA. Rev Pesq Saúde. 2013;14(3):175-8.

19. Xavier MI, Barreto ML. Tuberculose na cidade de Salvador, Bahia, Brasil: o perfil na década de 1990. Cad Saúde Pública. 2007;23(2):445-53. 